Case Report

\title{
Do Huntington`s Disease Patients Benefit From Multidisciplinary Inpatient Reha- bilitation?
}

\author{
Jens D. Rollnik
}

Institute for Neurorehabilitation Research, Medical School Hannover (MHH), Hessisch Oldendorf, Germany

\section{Received Date: May 26, 2015 \\ Accepted Date: June 17, 2015 \\ Published Date: June 22, 2015}

Corresponding author: Rollnik, J. D. Institute for Neurorehabilitation Research, Medical School Hannover (MHH), Hessisch Oldendorf, Germany. Tel +49 5152 781-231; Fax -198; E-mail: prof.rollnik@ bdh-klinik-hessisch-oldendorf.de

Citation: Rollnik, J.D. Do Huntington`s Disease Patients Benefit From Multidisciplinary Inpatient Rehabilitation? (2015) Int J Neurol Brain Disord 2(1): 18-22.

Keywords: Huntington disease; Rehabilitation; Multidisciplinary; Inpatient

\section{Introduction}

Huntington's disease (HD) is a late-onset, neurodegenerative and hereditary disease caused by a trinucleotide repeat expansion in exon 1 of the Huntingtin gene $(4 p 16.3)^{[1]}$. This expansion encodes a stretch of glutamine residues in the Huntingtin protein (HTT) which is essential in a variety of cellular functions, e.g. vesicle transport, transcription and energy production $^{[2]}$. Mutant HTT-induced toxicity ends up in death of striatal and cortical neurons inducing movement disorders (e.g. chorea, dystonia, akinesia, postural and gait disturbances), cognitive resp. psychiatric problems (attention and memory disorders, personality changes, frontal dementia, depression, psychosis, anxiety, aggressive and obsessive compulsive behavior), dysarthria and dysphagia ${ }^{[2-5]}$. Cognitive and motor symptoms are evident as early as 10 years prior to HD onset ${ }^{[6]}$. With disease ipation are significantly impaired. Many late-stage patients are dependent on help, up to $73.8 \%$ reside in nursing homes ${ }^{[7]}$. Survival time after diagnosis is $15-20$ years $^{[4]}$. In German speaking countries, one out of 10.000 inhabitants suffers from $\mathrm{HD}^{[8]}$.

Despite considerable efforts, including promising strategies like gene silencing, as yet no disease modifying therapy is available ${ }^{[2]}$. Only symptomatic treatment (e.g. tetrabenazine, tiapride or neuroleptics considered for chorea) may be offered to the patient ${ }^{[9]}$.

There is only limited scientific evidence to prove that progression, activities of daily living (ADL) and social partic-

\begin{abstract}
Huntington's disease (HD) is a neurodegenerative disease. Since no disease modifying medication is available until now, rehabilitation and other therapeutic approaches are of major interest. Some studies suggest that multidisciplinary rehabilitation may be beneficial in HD improving activities of daily living (ADL). Medical records of the BDH-Clinic Hessisch Oldendorf, a large rehabilitation facility in Northern Germany, have been carefully reviewed and three HD cases have been identified over the last decade. The patients have been treated with a three-week inpatient multidisciplinary rehabilitation program, including ADL-training, physical, cognitive, occupational and (in one case) speech therapy. All patients benefitted from inpatient rehabilitation. Two were discharged with a BI increase of 5 resp. 20 points. In one case, BI remained unchanged, but the patient's balance and gait markedly improved. Further controlled studies are needed but results from this small case series and findings from literature suggest that inpatient multidisciplinary rehabilitation is useful in HD.
\end{abstract}

physical, occupational and speech therapy, as well as multidisciplinary inpatient rehabilitation is effective in $\mathrm{HD}^{[10,11]}$.

Results from HD mouse models suggest that motor training, in particular in an enriched environment setting, may delay disease onset and progression ${ }^{[11-16]}$. Beneficial effects could be explained by increased brain-derived neurotrophic factor (BDNF) levels in hippocampal and striatal neurons ${ }^{[17]}$. Diminished BDNF synthesis and secretion - as well as oxidative stress - plays an important role in human HD pathophysiology ${ }^{[2,18]}$.

A couple of human studies have shown that physical therapy (physiotherapy, motor training), in particular exercise programs at patients `home, may be beneficial in $\mathrm{HD}^{[19-30]}$. Table 1 .

Table 1: Studies on physical therapy in HD

\begin{tabular}{|l|l|l|l|l|}
\hline Study & $\mathrm{n}$ & Sample & Intervention & Results \\
\hline $\begin{array}{l}\text { Banger, } \\
1980^{[19]}\end{array}$ & 5 & $\begin{array}{l}\text { Out } \\
\text { patients }\end{array}$ & $\begin{array}{l}\text { Home physiotherapy } \\
\text { (focus: muscle weak- } \\
\text { ness, range of move- } \\
\text { ment, gait, breathing) } \\
60 \text { min twice a week } \\
\text { for 4 weeks }\end{array}$ & $\begin{array}{l}\text { Objective outcome } \\
\text { measurements not } \\
\text { reported, subjec- } \\
\text { tive improvements } \\
\text { in alertness and } \\
\text { balance }\end{array}$ \\
\hline $\begin{array}{l}\text { Lavers, } \\
1981^{[20]}\end{array}$ & 6 & $\begin{array}{l}\text { Late- } \\
\text { stage } \\
\text { patients } \\
\text { on a } \\
\text { long- } \\
\text { term care } \\
\text { psychiat- } \\
\text { ric ward }\end{array}$ & $\begin{array}{l}\text { Weekly physiotherapy } \\
\text { and occupational ther- } \\
\text { apy over 12 months, } \\
\text { focusing on mobility, } \\
\text { balance, coordination, } \\
\text { contracture prevention, } \\
\text { social interaction }\end{array}$ & $\begin{array}{l}\text { Objective outcome } \\
\text { measurements not } \\
\text { reported, 2 patients } \\
\text { gained body weight }\end{array}$ \\
\hline
\end{tabular}

Copy rights: (C2015 Rollnik, J. D. This is an Open access article distributed under the terms of Creative Commons Attribution 4.0 International License. 


\begin{tabular}{|c|c|c|c|c|}
\hline $\begin{array}{l}\text { Peacock, } \\
1987^{[21]}\end{array}$ & 10 & $\begin{array}{l}\text { Early } \\
\text { to } \\
\text { mid- } \\
\text { stage } \\
\text { patients }\end{array}$ & $\begin{array}{l}\text { Weekly outpatient phys- } \\
\text { ical therapy program for } \\
3 \text { months ( } 45 \text { min), fol- } \\
\text { lowed by three monthly } \\
\text { sessions, designed to be } \\
\text { done at home between } \\
\text { therapy sessions with } \\
\text { no assistance necessary }\end{array}$ & $\begin{array}{l}\text { Objective outcome } \\
\text { measurements not } \\
\text { reported, "all pa- } \\
\text { tients improved" }\end{array}$ \\
\hline $\begin{array}{l}\text { Sheaff, } \\
1990^{[22]}\end{array}$ & 1 & $\begin{array}{l}\text { Case } \\
\text { Report } \\
\text { (severely } \\
\text { disabled } \\
\text { male) }\end{array}$ & $\begin{array}{l}\text { Hydrotherapy (gen- } \\
\text { tle exercises in water } \\
\text { supervised by a phys- } \\
\text { iotherapist(, unknown } \\
\text { period }\end{array}$ & $\begin{array}{l}\text { Objective outcome } \\
\text { measurements not } \\
\text { reported, "physio- } \\
\text { therapy was benefi- } \\
\text { cial" }\end{array}$ \\
\hline $\begin{array}{l}\text { Q u i n n } \\
\& \quad \text { Rao, } \\
2002[23]\end{array}$ & 1 & $\begin{array}{l}\text { Case } \\
\text { R e p o r t } \\
(49 \text { y old } \\
\text { male, liv- } \\
\text { ing at a } \\
\text { home) }\end{array}$ & $\begin{array}{l}\text { Home program (phys- } \\
\text { ical therapy) for } 14 \\
\text { weeks }\end{array}$ & $\begin{array}{l}\text { Improvement of SF- } \\
36 \text {, number of falls, } \\
\text { walking speed, Berg } \\
\text { Balance Scale }(+9) \text {, } \\
\text { UHDRS-TMS }(-12)\end{array}$ \\
\hline $\begin{array}{l}\text { B o h } 1 \text { e en } \\
\text { et al., } \\
2013^{[24]}\end{array}$ & 12 & $\begin{array}{l}\text { Out } \\
\text { patients } \\
\text { with no } \\
\text { risk to } \\
\text { fall }\end{array}$ & $\begin{array}{l}\text { Physical therapy ses- } \\
\text { sions, twice per week, } \\
60 \text { min for } 6 \text { weeks fo- } \\
\text { cusing on transfer train- } \\
\text { ing, walking, postural } \\
\text { stability, motor ccordi- } \\
\text { nation tasks }\end{array}$ & $\begin{array}{l}\text { Significant improve- } \\
\text { ment of gait param- } \\
\text { eters (GAITRite } ® \text { ), } \\
\text { Timed-,up \& go“", } \\
\text { Berg Balance Scale }\end{array}$ \\
\hline $\begin{array}{l}\text { Kloos et } \\
\text { al., } 2013 \\
{[25](\text { RCT })}\end{array}$ & 18 & $\begin{array}{l}\text { Out } \\
\text { patients, } \\
\text { able to } \\
\text { walk }\end{array}$ & $\begin{array}{l}2 \text { days per week } 45 \text { min } \\
\text { „Dance Dance Revolu- } \\
\text { tion“ for } 6 \text { weeks }\end{array}$ & $\begin{array}{l}\text { Significant improve- } \\
\text { ment ofgait parame- } \\
\text { ters (GAITRite } \AA \text { ) }\end{array}$ \\
\hline $\begin{array}{l}\text { K h a } 1 \text { i } 1 \\
\text { et al., } \\
2013^{[26]} \\
(\mathrm{RCT})\end{array}$ & 25 & $\begin{array}{l}\text { Early } \\
\text { to mid- } \\
\text { stage HD }\end{array}$ & $\begin{array}{l}\text { Exercises at home three } \\
\text { times a week for eight } \\
\text { weeks using an exercise } \\
\text { DVD }\end{array}$ & $\begin{array}{l}\text { Siginificant im- } \\
\text { provement of gait } \\
\text { speed, balance, } \\
\text { function and level of } \\
\text { physical activity }\end{array}$ \\
\hline $\begin{array}{l}\text { R e y e s } \\
\text { et al., } \\
2014^{[27]} \\
(\mathrm{RCT})\end{array}$ & 18 & $\begin{array}{l}\text { Out } \\
\text { patients } \\
\text { with UH- } \\
\text { DRS- } \\
\text { TMS } \\
\geq 5\end{array}$ & $\begin{array}{l}6 \text { times a week home- } \\
\text { based inspiratory and } \\
\text { expiratory (each } 5 \text { sets } \\
\text { of } 5 \text { repetitions) muscle } \\
\text { training for } 4 \text { months }\end{array}$ & $\begin{array}{l}\text { Significant improve- } \\
\text { ment of maximum } \\
\text { inspiratory/expirato- } \\
\text { ry pressures, forced } \\
\text { vital capacity, forced } \\
1 \mathrm{~s} \text { expiratory vol- } \\
\text { ume and peak expi- } \\
\text { ratory flow }\end{array}$ \\
\hline $\begin{array}{l}\text { Q u i n n } \\
\text { et al., } \\
20144^{[28]} \\
(\mathrm{RCT})\end{array}$ & 30 & $\begin{array}{l}\text { M i d - } \\
\text { stage HD }\end{array}$ & $\begin{array}{l}\text { Task-specific training } \\
\text { by physical therapists in } \\
\text { participants homes, fo- } \\
\text { cusing on walking, sit- } \\
\text { to-stand transfers and } \\
\text { standing, twice a week } \\
\text { for } 8 \text { weeks }\end{array}$ & $\begin{array}{l}92 \% \text { of individual } \\
\text { goals were achieved }\end{array}$ \\
\hline $\begin{array}{l}\text { M e t - } \\
\text { zler-Bad- } \\
\text { d e } 1 \text { e y } \\
2014 \\
{[29]}\end{array}$ & 10 & $\begin{array}{l}1 \quad \text { pre- } \\
\text { clinical, } \\
9 \text { early to } \\
\text { advanced } \\
\text { stages of } \\
\text { HD }\end{array}$ & $\begin{array}{l}\text { Rhythm exercise over } \\
\text { two months }\end{array}$ & $\begin{array}{l}\text { Improvements in } \\
\text { executive functions, } \\
\text { changes in white } \\
\text { matter microstruc- } \\
\text { tures (genu of the } \\
\text { corpus callosum) }\end{array}$ \\
\hline $\begin{array}{l}\text { Dawes et } \\
\text { al., } 2015 \\
\text { [30] }\end{array}$ & 30 & $\begin{array}{l}\text { Out } \\
\text { patients, } \\
\text { o } 1 \mathrm{~d} \text { e r } \\
\text { than } 18 \\
\text { y, able to } \\
\text { consent }\end{array}$ & $\begin{array}{l}\text { Once per week gym } \\
\text { intervention with sup- } \\
\text { port from a physical } \\
\text { therapist (20-30 min, } \\
\text { stationary cycle }), 10 \\
\text { min a day twice a week } \\
\text { walking quickly }\end{array}$ & $\begin{array}{l}\text { No adverse events, } \\
\text { no significant influ- } \\
\text { ence on heart rate }\end{array}$ \\
\hline
\end{tabular}

As far as occupational therapy is concerned, only one randomized-controlled trial (RCT) with a small sample size (12 patients of a long-term care unit) is available using multisensory stimulation ${ }^{[31]}$. Patients attended eight $30 \mathrm{~min}$ sessions (visual, tactile, auditory and olfactory stimulation) over four weeks.
The authors found no significant treatment effects ${ }^{[31]}$. In another study with only four participants, no improvement of ADL was evident after eight months ${ }^{[32]}$. In addition, some case reports suggest that occupational therapy may be beneficial ${ }^{[33-35]}$.

Treatment of dysphagia, dysarthria and aphasia is recommended in $\mathrm{HD}^{[36,37]}$, but evidence is weak ${ }^{[10,11]}$.

With respect to multidisciplinary rehabilitation, a couple of studies have been published ${ }^{[38-43]}$, table 2, two of them dealing with outpatient ${ }^{[39,43]}$, three with inpatient rehabilitation ${ }^{[38,40-42]}$. Duration of multidisciplinary rehabilitation was three weeks in all three inpatient studies and could be repeated up to three times per year in two of them ${ }^{[38,40]}$. The studies enrolled early to midstage HD patients. Improvements in ADL were reported by two studies $^{[38,41,42]}$. In one study, ADL remained stable with no significant decline ${ }^{[40]}$. In addition, gait and other parameters of motor performance improved in all three inpatient studies. Remarkably, one paper reported an influence of inpatient multidisciplinary rehabilitation on neural oxidative damage (significant decrease of $\mathrm{Cu} / \mathrm{Zn}$-superoxide dismutase and neuron-specific enolase levels) suggesting a disease modifying effect of this intervention ${ }^{[42]}$.

Table 2: Studies on multidisciplinary rehabilitation in HD

\begin{tabular}{|c|c|c|c|c|}
\hline Studie & $\mathrm{n}$ & Sample & Intervention & Outcome \\
\hline $\begin{array}{l}\text { Zinzi et } \\
\begin{array}{l}\text { al., } \\
{[38]}\end{array}\end{array}$ & 40 & $\begin{array}{l}\text { Early to } \\
\text { mid- } \\
\text { stage } \\
\text { HD in- } \\
\text { patients }\end{array}$ & $\begin{array}{l}\text { Respiratory exercises, } \\
\text { speech, physical and } \\
\text { occupational therapy, } \\
\text { cognitive exercise, } \\
\text { three week inpatient } \\
\text { rehabilitation (repeated } \\
\text { up to } 3 \text { times per year) }\end{array}$ & $\begin{array}{l}\text { Significant improve- } \\
\text { ment of motor per- } \\
\text { formance and ADL } \\
(\mathrm{p}<0.001) \text {, no motor } \\
\text { decline over two } \\
\text { years }\end{array}$ \\
\hline $\begin{array}{l}\text { (Thomp- } \\
\text { son et al., } \\
2013^{[39]} \\
\text { RCT) }\end{array}$ & 20 & $\begin{array}{l}\text { Early to } \\
\text { mid- } \\
\text { stage } \\
\text { HD out- } \\
\text { patients }\end{array}$ & $\begin{array}{l}\text { 9-month multidisci- } \\
\text { plinary rehabilitation } \\
\text { program (once weekly } \\
60 \text { min), occupation- } \\
\text { al therapy targeting } \\
\text { cognitive deficits (6 } \\
\text { months, } 60 \text { min per } \\
\text { fortnight) and home } \\
\text { exercises ( } 6 \text { months, } 3 \\
\text { times per week) }\end{array}$ & $\begin{array}{l}\text { Reduction of motor } \\
\text { and postural stability } \\
\text { deterioration, minor } \\
\text { improvements in de- } \\
\text { pression, cognition } \\
\text { and quality of life }\end{array}$ \\
\hline $\begin{array}{lr}\text { Piira } & \text { et } \\
\text { al., } & 2013 \\
{[40]} & \end{array}$ & 37 & $\begin{array}{l}\text { Early to } \\
\text { mid- } \\
\text { stage } \\
\text { HD in- } \\
\text { patients }\end{array}$ & $\begin{array}{l}1 \text { y rehabilitation pro- } \\
\text { gram ( } 3 \text { admissions of } \\
3 \text { weeks each) focusing } \\
\text { on physical exercise, } \\
\text { social activities, and } \\
\text { group/teaching ses- } \\
\text { sions }\end{array}$ & $\begin{array}{l}\text { Improvements in gait } \\
\text { function, balance, } \\
\text { physical quality of } \\
\text { life, anxiety and } \\
\text { depression, BMI; } \\
\text { ADL-function re- } \\
\text { mained stable with } \\
\text { no significant decline }\end{array}$ \\
\hline $\begin{array}{l}\text { Ciancar- } \\
\text { elli et al., } \\
2013^{[41]} \text {; } \\
\text { Ciancar- } \\
\text { elli et al., } \\
2014^{[42]}\end{array}$ & 34 & $\begin{array}{l}\text { HD } \\
\text { inpa- } \\
\text { tients } \\
\text { (mean } \\
\text { BI } 77 \\
\text { points) }\end{array}$ & $\begin{array}{l}\text { 3-week inpatient in- } \\
\text { tensive multifunctional } \\
\text { neurorehabilitation, } 2 \mathrm{x} \\
120 \text { min group therapy } \\
\text { daily (physical and oc- } \\
\text { cupational therapy) }\end{array}$ & $\begin{array}{l}\text { Significant increase } \\
\text { of the mean scores } \\
\text { of BI, TS, PPT and } \\
\text { TFCS }(\mathrm{p}<0.001) \text {, re- } \\
\text { duction of oxidative } \\
\text { stress, parameters of } \\
\text { neurodegeneration } \\
(\mathrm{Cu} / \mathrm{Zn}-\mathrm{SOD}, \mathrm{NSE})\end{array}$ \\
\hline $\begin{array}{l}\text { Cruick- } \\
\text { shank et } \\
\text { al., } 2015 \\
{[43]}\end{array}$ & 15 & $\begin{array}{l}\text { Out } \\
\text { patients, } \\
\text { U H - } \\
\text { DRS- } \\
\text { TMS > 5 }\end{array}$ & $\begin{array}{l}9 \text { months once-week- } \\
\text { ly supervised clinical } \\
\text { exercise, thrice-week- } \\
\text { ly self-directed home } \\
\text { based exercise and } \\
\text { fortnightly occupation- } \\
\text { al therapy }\end{array}$ & $\begin{array}{l}\text { Significantly in- } \\
\text { creased gray matter } \\
\text { volume in the right } \\
\text { caudate and bilater- } \\
\text { ally in the DLPFC, } \\
\text { significant improve- } \\
\text { ments in verbal } \\
\text { learning and memo- } \\
\text { ry (Hopkins Verbal } \\
\text { Learning-Test) }\end{array}$ \\
\hline
\end{tabular}


BI $=$ Barthel-index, TS $=$ Tinetti Scale, PPS $=$ Physical Performance Test, TFCS $=$ Total Functional Capacity Test, $\mathrm{Cu} / \mathrm{Zn}-\mathrm{SOD}=\mathrm{Cu} / \mathrm{Zn}$-Superoxid-Dismutase, NSE $=$ Neuron-specific enolase

There is only little data on the effectiveness of multidisciplinary inpatient rehabilitation in HD. Thus, last decade medical records of the BDH-Clinic Hessisch Oldendorf, a large neurological rehabilitation center located in Northern Germany, have been carefully reviewed. Three inpatient rehabilitation HD cases have been identified and analyzed.

\section{Case Presentation}

\section{Case 1}

A 48 year old male with genetically confirmed HD (45 CAG repeats) was admitted to inpatient rehabilitation because of a deterioration of ADL. Age of onset was 43. The patient suffered from dysphagia, chorea and mild frontal dementia. Due to an aspiration pneumonia in the past, the patient already had a percutaneous endoscopic gastrostomy (PEG) tube. A computer tomography $(\mathrm{CT})$ of the skull revealed a marked brain atrophy, in particular of the frontal lobes, Figure 1.

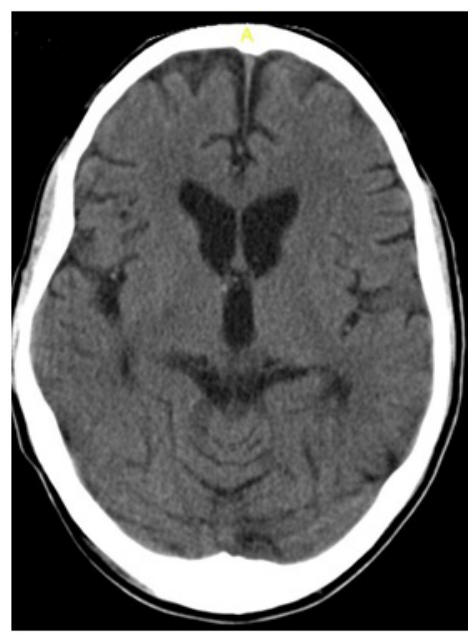

Figure 1: CT scan of case 1.

He was still living at home with some help from his mother and working in a sheltered workshop. The patient was on tiapride $300 \mathrm{mg} / \mathrm{d}$, tetrazepam $100 \mathrm{mg} / \mathrm{d}$ and memantine 90 $\mathrm{mg} / \mathrm{d}$.

The three-week inpatient multidisciplinary rehabilitation program included 60 min cognitive training (computing tasks, writing, communication skills), 30 min occupational therapy (fine motor skills) and $120 \mathrm{~min}$ ADL-training daily (total $210 \mathrm{~min} / \mathrm{d})$.

On admission, the Barthel index (BI) was 70, and the patient was discharged home with a BI of $90(\Lambda=20)$.

Case 2

A 20 year old female with clinical diagnosis of HD (not genetically confirmed) was admitted to inpatient rehabilitation because of increasing cognitive problems (memory, disorientation) and schizophrenic psychosis. Age of onset was 17. She was suffering from dysarthria, eye saccade disturbances, motor impersistence, ataxic gait, dysdiadochokinesis, dysmetria (all four extremities). Luria's test was positive on admission. A magnetic resonance imaging (MRI) revealed global brain atrophy, Figure 2.

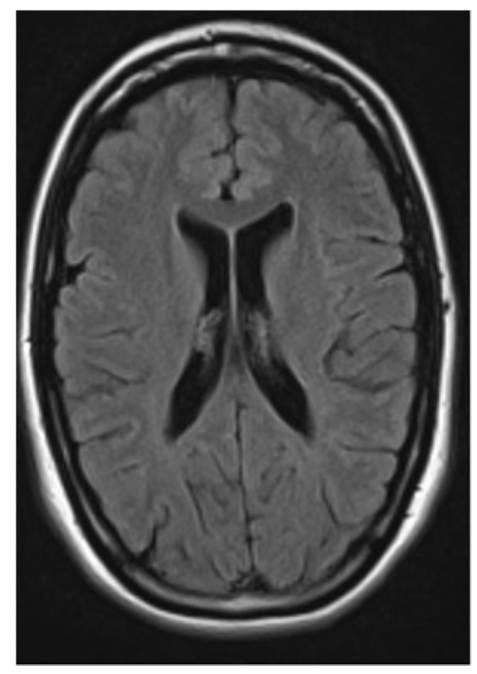

Figure 2: MRI (T2 FLAIR) of case 2.

The patient was living with her parents who were taking care of her. She used to work in a nursing home but since months, she was unable to work. The patient was on tiapride 300 $\mathrm{mg} / \mathrm{d}$, olanzapine $30 \mathrm{mg} / \mathrm{d}$ and lorazepam $2 \mathrm{mg} / \mathrm{d}$.

The three-week inpatient multidisciplinary rehabilitation included 75 min cognitive training (memory, orientation), 30 min occupational therapy (fine motor skills), 90 min physical therapy (balance, gait) and $180 \mathrm{~min}$ ADL-training daily (total $375 \mathrm{~min} / \mathrm{d}$ ).

On admission, BI was 60, and the patient was discharged home with a BI of $65(\Lambda=5)$.

\section{Case 3}

A 59 year old female with clinical diagnosis of HD (not genetically confirmed) was admitted to inpatient rehabilitation because of deterioration of ADL. Age of onset was unclear, at least three years ago. She was suffering from chorea, severely ataxic gait (with a history of falls), dysphasia and cognitive problems (disorientation, memory, attentiveness). A magnetic resonance imaging (MRI) revealed marked brain atrophy (with hydrocephalus) and diffuse white matter changes, Figure 3.

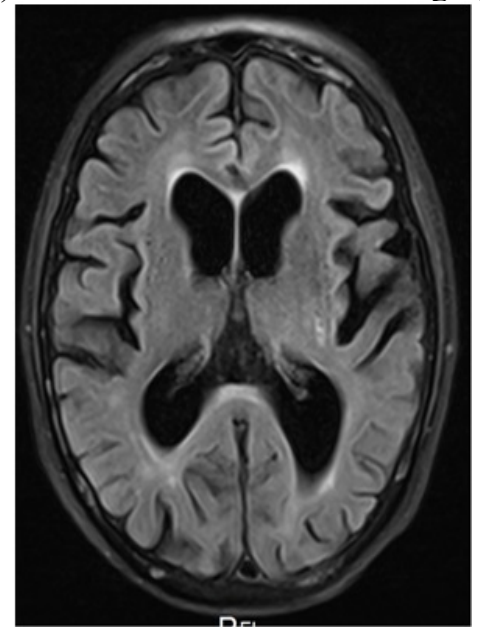

Figure 3: MRI (T2 FLAIR) of case 3.

The patient was still living at home but she was found neglected in her apartment, with a BMI of only $18.2 \mathrm{~kg} / \mathrm{m}^{2}$. She was jobless for years. The patient was on tiapride $200 \mathrm{mg} / \mathrm{d}$ and 
quetiapine $50 \mathrm{mg} / \mathrm{d}$.

The three-week inpatient multidisciplinary rehabilitation included 30 min cognitive training (communication skills), 20 min speech therapy, 60 min occupational therapy (fine motor skills, working in the kitchen), 60 min physical therapy (balance, gait) and $180 \mathrm{~min}$ ADL-training daily (total $350 \mathrm{~min} / \mathrm{d}$ ).

On admission, the Barthel index (BI) was 70, and the patient was discharged to a nursing home with a BI of $70(\Lambda=0)$. Despite a lack of BI changes, her balance and gait were much better at discharge and she was able to walk a short distance without assistive device.

TheBIvalues ofall threepatientsare displayedinFigure 4.

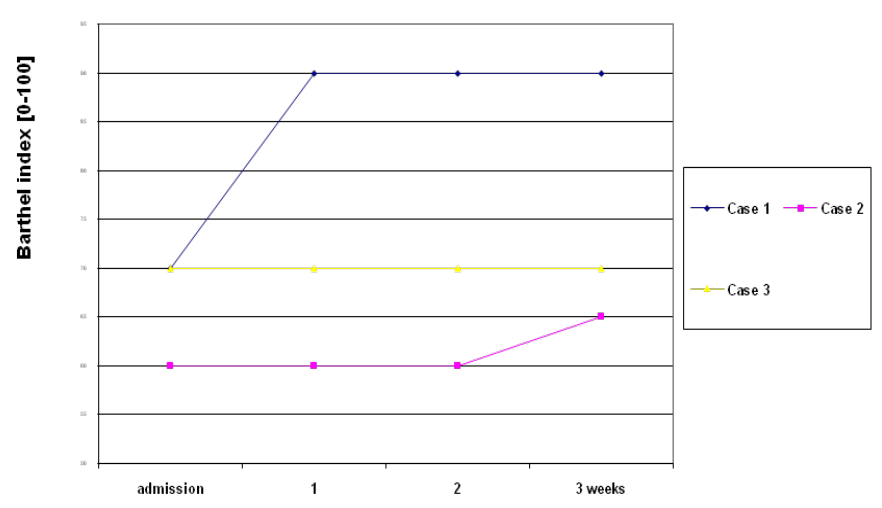

Figure 4: Barthel index of the three cases on admission and after 1, 2 and 3 weeks of inpatient rehabilitation.

\section{Discussion}

HD is a neurodegenerative, severely disabling disease. While no disease-modifying medication is available until now, rehabilitation and other therapeutic interventions are of major interest. Some studies suggest that physical therapy is beneficial in $\mathrm{HD}^{[19-30]}$. Many patients, however, suffer from severe impairments of their social participation. They are in need of multidisciplinary (inpatient) rehabilitation. A couple of studies have demonstrated that multidisciplinary rehabilitation is useful to improve ADL, as shown by increases of $\mathrm{BI}^{[38,41,42]}$.

Since data on this topic is rare, HD inpatient rehabilitation cases of the BDH-Clinic Hessisch Oldendorf, Germany, have been carefully reviewed. Three HD cases have been identified over the last decade. Diagnosis was genetically confirmed in one case, only. However, the clinical diagnoses in the other two cases was most certain since competing diagnoses have been excluded reliably.

The HD patients have been treated with a three-week inpatient multidisciplinary rehabilitation program, including ADL-training, physical, cognitive, occupational and (in one case) speech therapy. All patients benefitted from the inpatient rehabilitation. Two were discharged with a BI increase of 5 rep. 20 points. In one case, BI was unchanged, but the patient's balance and gait was markedly better. The results from this small case series are in line with previous studies which have demonstrated significant improvements through a three-week multidisciplinary inpatient rehabilitation ${ }^{[38,41,42]}$. Although the length of stay in rehabilitation was brief (three weeks) for patients who suffer from long-term, progressive functional decline, ADL im- proved.

Further controlled studies are needed but results from literature and this small case series supports the hypothesis that multidisciplinary rehabilitation in HD is useful.

\section{References}

1. A novel gene containing a trinucleotide repeat that is expanded and unstable on Huntington's disease chromosomes. Huntington's Disease Collaborative Research Group. (1993) Cell 72(6): 971-983.

2. Rollnik, J.D. Morbus Huntington. (2015) Der Nervenarzt 86(6): 725735 .

3. Gasser, T. Chorea Huntington and Chorea Sydenham. In: Brandt T, Dichgans J, Diener HC, Hrsg. Therapie und Verlauf neurologischer Erkrankungen. (1998) Stuttgart: Kohlhammer 915-921.

4. Lücking, C. H., Amtage, F., Hummel, S., et al. Huntington-Erkrankung. In: Hufschmidt A, Lücking CH, Rauer S, Hrsg. Neurologie compact. (2013) Stuttgart Thieme360-364.

5. Weindl, A., Conrad, B.Chorea and choreic movement disorders. In: Conrad B, Ceballos-Baumann AO, Ed. Movement disorders in neurology. (1996) Stuttgart Thieme 155-180.

6. Chandra, A., Johri, A., Beal, M. F. Prospects for neuroprotective therapies in prodromal Huntington`s disease. (2014) Mov Disord 29(3): 285-293.

7. Anderson, K. E., Divino, V., DeKoven, M., et al. Interventional differences among Huntington's disease patients by disease progression in commercial and medicaid populations. (2014) J Huntingtons Dis 3(4): 355-363.

8. Laccone, F., Engel, U., Holinski-Feder, E., et al. DNA analysis of Huntington's disease: five years of experience in Germany, Austria, and Switzerland. (1999) Neurology 53(4): 801-806.

9. Armstrong, M. J., Miyasaki, J. M. Evidence-based guideline: pharmacologic treatment of chorea in Huntington disease: report of the guideline development subcommittee of the American Academy of Neurology. (2012) Neurology 79(6): 597-603.

10. Bilney, B., Morris, M. E., Perry, A. Effectiveness of physiotherapy, occupational therapy, and speech pathology for people with Huntington's disease: a systematic review. (2003) Neurorehabil Neural Repair 17(1): 12-24.

11. Rollnik, J. D. Rehabilitation in Huntington`s disease. (2015) Fortschr Neurol Psychiatr.

12. van Dellen, A., Cordery, P. M., Spires, T. L., et al. Wheel running from a juvenile age delays onset of specific motor deficits but does not alter protein aggregate density in a mouse model of Huntington's disease. (2008) BMC Neurosci 9: 34.

13. van Dellen, A., Blakemore, C., Deacon, R., et al. Delaying the onset of Huntington's in mice. (2000) Nature 404: 721-722.

14. Skillings, E. A., Wood, N. I., Morton, A. J. Beneficial effects of environmental enrichment and food entrainment in the R6/2 mouse model of Huntington's disease. (2014) Brain Behav 4(5): 675-686.

15. Wood, N. I., Glynn, D., Morton, A. J. "Brain training” improves cognitive performance and survival in a transgenic mouse model of Huntington's disease. (2011) Neurobiol Dis 42(3): 427-437.

16. Harrison, D. J., Busse, M., Openshaw, R., et al. Exercise attenuates neuropathology and has greater benefit on cognitive than motor deficits in the R6/1 Huntington's disease mouse model. (2013) Exp Neurol 248: 457-469.

17. Li, L., Tang, B. L. Environmental enrichment and neurodegenerative diseases. (2005) Biochem Biophys Res Commun 334(2): 293-297. 18. Wild, E. J., Tabrizi, S. J. Targets for future clinical trials in Huntington's disease: what's in the pipeline? (2014) Mov Disord 29(11): 1434-1445.

19. Binswanger, C. Physical therapy in Huntington disease. (1980) Arch Phys Med Rehabil 61(3): 148.

20. Lavers, A. An account of a weekly activity group with Huntington's chorea patients on a long stay ward. (1981) Occup Ther 44: 387-392. 
21. Busse, M. E., Khalil, H., Quinn., L., et al. Physical therapy intervention for People with Huntington disease.(2008)Phys Ther 88(7): 820-831.

22. Sheaff, F. Hydrotherapy in Huntington's disease. (1990) Nurs Times 86(4): 46-49.

23. Quinn, L., Rao, A. Physical therapy for people with Huntington disease: current perspectives and case report. (2002) Neurol Rep 26: 145-153.

24. Bohlen, S., Ekwall, C., Hellström, K., et al. Physical therapy in Huntington's disease--toward objective assessments? (2013) Eur J Neurol 20(2): 389-393.

25. Kloos, A. D., Fritz, N. E., Kostyk, S. K., et al. Video game play (Dance Dance Revolution) as a potential exercise therapy in Huntington's disease: a controlled clinical trial. (2013) Clin Rehabil 27(11): 972-982.

26. Khalil, H., Quinn, L., van Deursen, R., et al. What effect does a structured home-based exercise programme have on people with Huntington's disease? A randomized, controlled pilot study. (2013) Clin Rehabil 27(7): 646-658.

27. Reyes, A., Cruickshank, T., Nosaka, K., et al. Respiratory muscle training on pulmonary and swallowing function in patients with huntington's disease: a pilot randomized controlled trial. (2014) Clin Rehabil.

28. Quinn, L., Debono, K., Dawes, H., et al. Task-specific training in Huntington disease: a randomized controlled feasibility trial. (2014) Phys Ther 94(11): 1555-1568.

29. Metzler-Baddeley, C., Cantera, J., Coulthard, E., et al. Improved Executive Function and Callosal White Matter Microstructure after Rhythm Exercise in Huntington's Disease. (2014) J Huntingtons Dis 3(3): 273-283.

30. Dawes, H., Collett, J., Debono, K., et al. Exercise testing and training in people with Huntington's disease. (2015) Clin Rehabil 29(2): 196-206.

31. Leng, T. R., Woodward, M. J., Stokes, M. J., et al. Effects of multisensory stimulation in people with Huntington's disease: a randomized controlled pilot study. (2003) Clin Rehabil 17(1): 30-41.

32. Mason, J., Andrews, K., Wilson, E. Late stage Huntington`s disease: effect if treating disabilities. (1991) Br J Occup Ther 54(1): 4-8.

33. Di Scipio, W. J., Hannesson, M. E. Neuromuscular facilitation in the treatment of Huntington`s chorea. (1971) Behav Neuropsychiatry 2(9): 13-14.

34. Blacker, D., Broadhurst, L., Teixeira, L. The role of occupational therapy in leisure adaptation with complex neurological disability: a discussion using two case study examples. (2008) Neurorehabilitation 23(4): 313-319.

35. Fenech, A., Baker, M. Casual leisure and the sensory diet: a concept for improving the quality of life in neuropalliative conditions. (2008) Neurorehabilitation 23(4): 369-376.
36. Hamilton, A., Ferm, U., Heemskerk, A. W., et al.. Management of speech, language and communication difficulties in Huntington's disease. (2012) Neurodegen Dis Manage 2(1): 67-77.

37. Kagel, M. C., Leopold, N. A. Dysphagia in Huntington's disease: a 16-year retrospective. (1992) Dysphagia 7(2): 106-114.

38. Zinzi, P., Salmaso, D., De Grandis, R., et al. Effects of an intensive rehabilitation programme on patients with Huntington's disease: a pilot study. (2007) Clin Rehabil 21(7): 603-613.

39. Thompson, J. A., Cruickshank, T. M., Penailillo, L. E., et al. The effects of multidisciplinary rehabilitation in patients with early-to-middle-stage Huntington's disease: a pilot study. Eur J Neurol 20(9): 13251329.

40. Piira, A., van Walsem, M. R., Mikalsen, G., et al. Effects of a One Year Intensive Multidisciplinary Rehabilitation Program for Patients with Huntington's Disease: a Prospective Intervention Study. (2013) PLoS Curr 5.

41. Ciancarelli, I., Tozzi Ciancarelli, M. G., Carolei, A. Effectiveness of intensive neurorehabilitation in patients with Huntington's disease. (2013) Eur J Phys Rehabil Med 49(2): 189-195.

42. Ciancarelli, I., De Amicis, D., Di Massimo, C., et al. Influence of intensive multifunctional neurorehabilitation on neuronal oxidative damage in patients with Huntington's disease. (2014) Funct Neurol 16: 1-6. 43. Cruickshank, T. M., Thompson J, A., Domínguez, D. J. F., et al. The effect of multidisciplinary rehabilitation on brain structure and cognition in Huntington's disease: an exploratory study. (2015) Brain Behav 5(2): $1-10$
Online ISSN: $2377-1348$

Journal Title: International Journal Neurology and Brain Disorders Journal Short Name: Int J Neurol Brain Disord
Ommega Online Publishers

E-mail: neurology@ommegaonline.com

Website: www.ommegaonline.com 